\title{
BOOK REVIEW: PROBLEMATIC WILDLIFE: A CROSS-DISCIPLINARY APPROACH
}

\author{
S. Suresh Ramanan', Anatoliy A. Khapugin ${ }^{2,3}$ \\ ${ }^{1}$ Kerala Agricultural University, India \\ e-mail:sureshramanan01@gmail.com \\ ${ }^{2}$ Mordovia State Nature Reserve, Russia \\ ${ }^{3}$ Mordovia State University, Russia \\ e-mail: hapugin88@yandex.ru
}

Received: 10.03.2017

PROBLEMATIC WILDLIFE: A CROSSDISCIPLINARY APPROACH, EDITED BY: FRANCESCOM.ANGELICI.CHAM: SPRINGER INTERNATIONAL, 2016, XVI + 603 PAGES, ISBN 978-3-319-22245-5, PRICE: \$159.00; ISBN 978-3-319-22246-2 (eBOOK), PRICE: \$119.00.

«Problematic Wildlife: A Cross-Disciplinary Approach» is a book appropriately titled. It is devoted to a current and hot area in wildlife. It is a compiled book of 26 chapters edited by Francesco $\mathrm{M}$. Angelici of Fondazione Italiana per la Zoologia dei Vertebrati (FIZV), Italy. The book contains case studies with detailed maps, descriptions and copious illustrations. The main objective of the book, as highlighted in the preface, is to spotlight the concept of problematic species, thus describing about the cross-cutting issue, the man-animal conflict and the need for changes in the management strategies which are pictured through case studies in the book. To have a better interpretation, the book is divided into parts ensuring easy reading by commencing with an overview. The book, in our opinion, can be aptly commented on as an interesting and intriguing work.

Dr Francesco Angelici, as the editor, has to be given the credits of aggregating and assembling the works of several authors to assimilate a comprehensive work on the current area of wildlife management. The content of the book is divided into nine parts. The concept and definition of problematic species and the justification of the book are highlighted in part I, whereas the issue of extinction of species and some case studies are in part II. A distinct concept of when does a wild animal becomes a problem is presented in part III, while part IV, V and VI detail about problematic species that are troubling human as well as their management in both protected area and in other areas. The topics in part VII and VIII are very specific and unique, pertaining to some cases like bush meat, bird strikes in the aviation sector and electrocution. Finally, part IX deals with the fallacious concept of cryptozoology.

Part I has a single chapter that begins with a saying "It is not man who has to fight against a hostile nature, but nature is helpless and for generations has been the victim of humanity"y. The chapter gives also a strong introduction to the book and its focal theme area: Problematic species. The matter pertaining to mammals' extinction and their decline across geographic patterns as well as taxonomic patterns are pictured along with its causes in chapter 2 of part II. Chapters 3 and 4 contain a prologue on the lion's population in Africa, and the subject of commodification of the Saker Falcon (Falco cherrug Gray, 1834), a Palearctic bird, is bonded with case studies in Mongolia. A briefing about the successful steps taken for the recovery of the otter population in the river Ticino in Italy is comprehended in chapter 5.

Part III examines the situation where wildlife creates problems. In spite of having many cases and examples, the book takes a look at the general management of problematic species. Chapter 6 sets the background for interpreting how the problem has to be addressed by various stakeholders. The practical and legal tools have also been explained in it. Chapter 7, on «Managing human-elephant conflict in Zimbabwe: a boundary perspective rather than a problematic species issue», has a much relevant context for India. Similarly, chapter 8 , by Rajaratnam with co-authors, is a crisp 
account of the issue pertaining livestock predation by large carnivores in Bhutan which borders India. It indirectly depicts a similar condition in India. This is followed by a chapter on the management techniques to control wildlife damage in an urbanized environment with an example from the USA. But it has lessons for a regional context, too, especially in North India, where macaques are creating a problem in the daily basis. The last chapter deals with a very interesting case of the parakeet being explained in the unthinkable perspective which may induce curiosity and debate among readers. The previous chapters are about usual problematic species, i.e. wild boar and rats.

Overall, part III and IV are the foundation chapters and do great justice to the book on the whole. Part V, with three chapters, deals with a genetic contribution to the management of problematic species. Many technical matters are detailed in these chapters. But the next part is very colourful and indeed deals with a very complex issue of man eaters, human death and attack by animals, even though case studies are pertaining to the wolf and apes, still it has stuff and content. The last chapter of this part begins with a saying: «A management consultant once said; "If you can't measure something, you can't manage it"》 which very well explains the essence of the chapter. It concerns the solution by measuring the conflict incident via mobile data in an African context.
Bird-strikes in the aviation sector and electrocution incidents of birds are not a generally discussed issue, but it has been around for years. The conflict, its impact and the steps needed for understanding as well as reducing the conflict due to the flying fauna are dealt with in the consecutive chapters 20, 21, 22. Part VII of the book highlights the issue of hidden and long-term, as well as direct, impact on birds by wind farms as one of the best renewable form of energy source. Bush meat or illegal trade in meat of wildlife is widespread in tropical Asia, Africa and South America; it is the source of food, medicines and proteins. There are many conflict ideologies on bush meat as they accelerate the threat and the rate of extinction of many species. Still more detailing is in chapter 24 which is followed by an immense problem - wildlife trade focusing on internet as a market place. It is a chapter that shatters our belief that wildlife trade is done in the underworld only. In the concluding part IX, «Hidden Species: An Appropriate Scientific Approach to Cryptozoology», there is a review chapter by Rossi. Indeed, the author has taken pains to bring out the scientific nature of a pseudoscience.

The book emerges as a keyhole for the greater door of wildlife management which can contribute to a better understanding. A book of this sort is recommended for wildlife and forestry students. It can also widen the perspective of policy makers on problematic species by paving a better way of sorting it.

\title{
РЕЦЕНЗИЯ НА КНИГУ: РROBLEMATIC WILDLIFE: A CROSS-DISCIPLINARY APPROACH
}

\author{
С. С. Раманан ${ }^{1}$, А. А. Хапугин ${ }^{2,3}$ \\ ${ }^{1}$ Кералский сельскохозяйственный университет, Индия \\ e-mail: sureshramanan01@gmail.com \\ ${ }^{2}$ Мордовский государственныій природный заповедник имени П.Г. Смидовича, Россия \\ ${ }^{3}$ Мордовский государственный университет имени Н.П. Огарева, Россия \\ e-mail: hapugin88@yandex.ru
}

